\title{
Merleau-Ponty meets enactivism \\ A book review of The Intercorporeal Self. Merleau-Ponty on Subjectivity
}

Author: Scott L. Marratto

Publisher: SUNY Press

Release Date: 2012

Number of Pages: 254

Jakub Ryszard Matyja

University of Huddersfield,

Polish Academy of Sciences

jrmatyja[lgmail.com

Received, accepted and published winter 2014/2015.

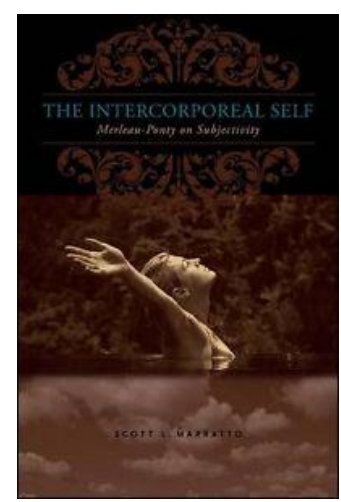

S. L. Marratto's excellent book explores the resources for thinking about the subjectivity that comes from reading Maurice Merelau-Ponty. Interested particularly in Merelau-Ponty's notion of intercorporiety (which denotes specific dimensions of anonymity characterising the personal body experience that lies beneath explicit self-consciousness), Marratto argues that no account of cognition (or self-consciousness and language) can be sufficient without the appreciation of the intercorporeal character of subjectivity. In that sense, drawing upon Merleau-Ponty's philosophy, the book aims to demonstrate (1) the importance of the concept of intercorporeity in deepening our understanding of the fundamentally intersubjective character of human selfconsciousness, and argues that (2) the intercorporeal character of human subjectivity is resistant to any form of reductionism, which is often found in current interdisciplinary cognitive science. In that sense, it would be however a mistake to assume that The Intercorporeal Self is of great importance solely to the history of philosophy-centered research. In his book, Marratto tackles important contemporary issues found in ecological, embodied, enactive or simply "situated" approaches to cognition. 
The Intercorporeal Self consists of a total of five chapters. In the opening Chapter ("Situation and the Embodied Mind"), the author explores MerleauPonty's accounts of sensation and space. Marratto is far from providing his analysis in a solely historical context. Rather, he develops his framework for interpretation of subjectivity by reading the works of French phenomenologist alongside recent works of 'situated cognition' by which he adopts a sensorimotor enactivist approach to perception advocated by Alva Noë \& Kevin J. O'Regan and J.J. Gibson's ecological psychology. All three of the approaches discussed in this chapter have a common aim to overcome the epistemology of (mental) representations that lies, as Marratto aptly recognises, at the very core of modern accounts of the epistemological subject. In an introductory manner, Marratto begins by showing the ways in which the subject of perception is first and foremost a "self-moving subjectivity" or "a tacit decision" that lets the environmental features appear as meaningful for sentient bodies. The importance of these two Merleau-Ponty-ian concepts enables the researchers working in the field of situated cognition-claims Marratto-to overcome some of the traditionally assumed oppositions (including: sensation vs. understanding, stimulus vs. response, cause vs. effect and others). The author of The Intercorporeal Self thus puts forward the assumption that the subject is situated insofar as its behavior is directly responsive to the upcoming information and its behaviour is in fact a form of decision concerning the meaning and the value that the organism ascribes to that information. This view remains in opposition to modern (representationalist) epistemology - specifically the idea that human cognition consist of operations inherently performed on tokens of the external world. Modern epistemology, however, it may be argued leaves out the question of subjectivity. This points to the explanatory gap between the $1^{\text {st }}$ and $3^{\text {rd }}$ person's perspective, while Merleau-Ponty's writing explicitly challenges the presuppositions of the epistemology of (mental) representations. Here Marratto moves to unearthing the further challenges that a return to French phenomenologist writings may pose for cognitivist accounts of cognition. The core argument here is that without the proper understanding of human situatedness there is little to be learned from the neural underpinnings of our cognitive processes. Interestingly, however, Marratto continues, challenging the situated approaches to cognition by showing that they should in fact be understood and further developed in two mutually reinforcing senses: (1) an epistemological sense (cognitive processes as directly grounded in sensorimotor processing - not the internal mapping-of the external world), and (2) an ontological sense (where the scrutiny should be not of how we use the information about the objective world, but rather of the investigation of the manner in which world is; the question then becomes focused on the ways in which cognition reveals the ontological dynamics that underlay the co-belonging and differences between subjectivity and its objects). 
In the second chapter ("Making Space"), the Author draws on the implications of Merelau-Ponty's account of perception-as-movement with respect to the problems of sensation, space, and the unity of the sentient body. In this chapter, Marratto provides his view on linking French phenomenologists' views with the question of what motivates organisms' learning. He claims that: "[t]he mode of being of the subjects is a responsitivity to what it cannot anticipate, and thus its identity is achieved only through a constant process of selftransformation, of the formation of new habits" (p. 7). In that sense, MerleauPonty's analysis of sensation entails a certain type of understanding of the temporal structure of our experience, where perception is always temporally spread (as in the ecological and sensorimotor approaches to cognition discussed in Marratto's book). The main aim of this chapter is to show and discuss the ways in which Merleau-Ponty's philosophy is concerned with the emergence of the structure within behavior, as well as the ways in which his account of the notion of sensation is crucial for understanding his argument about the character of this emergence. This leads to a detailed discussion of the notion of affordances (in J. J. Gibson's ecological psychology's sense), which serves as another important contribution to current discussions in situated approaches to cognition.

In the third Chapter of his book ("Subjectivity and the 'Style' of the World") the Author returns to reconsidering sensorimotor and ecological accounts of perception discussed in the opening chapter. His main argument here is that both of these approaches (aimed to naturalise phenomenology) do end up appealing to what Merleau-Ponty called a "ready-made" world, and therefore miss the ontological originality of the phenomena of perception, while also (importantly for the purpose of the book) avoiding the fundamental problems of subjectivity. Marratto raises an argument that without a fundamental ontological investigation of the modes of being of environments and selves no challenge to the epistemology of representation can be complete. Epistemology, in this sense, is inherently linked to the commitments remaining as the presupposition in the idea of 'naturalised phenomenology'. Marratto further investigates the differences between contemporary approaches to the problem of depth in terms of temporality of experience and sensorimotor subjectivity as proposed by contemporary sensorimotor enactivists (Alva Noë \& Kevin J. O'Regan, Evan Thompson), phenomenologists (Dan Zahavi) as well as cognitive psychologists like Ulrich Neisser.

In Chapter 4 ("Auto-affection and Alterity"), Marratto examines the French philosopher's account of time as auto-affection that must be understood as a claim concerning the temporalising character of living movement. In this chapter the Author also responds to other commentators on Merelau-Ponty who read this issue as an example of the latter's commitment to a "metaphysics of presence” [p. 8]. Here Marratto also examines Jacques Derrida's deconstructionist interpretation of the phenomenological notions of consciousness 
and auto-affection, as well as "intercorporiety". This chapter serves as a detailed discussion of the relevance of Derrida's works on language and the lived body to the topic of the book. It also provides a discussion on the notions of "body schema" and "body image" (focusing on the works of Shaun Gallagher and Dan Zahavi) that-according to Marratto's argumentation-we need to go beyond in order to achieve the aims assumed at the beginning of the book. In the final Chapter of his book ("Ipseity and Language"), the Author responds to those interpreters of Maurice Merleau-Ponty's philosophy who hold that (in Phenomenology of Perception) French phenomenologist privileges perception over language. This chapter also contains an interesting discussion of the meaning conveyed or expressed by (embodied) gestures, which is important to those interested in embodied and situated cognition.

In conclusion, Marratto's book serves as an important contribution to current studies on the relevance of traditional phenomenology to recent works in embodied, enactive and situated approaches to cognition. Written in an approachable and clear style, this book is of value both to advanced scholars as well as those who are just beginning their academic journey. Personally, I found Marratto's suggestion for considering situated approaches to cognition on the mutually reinforcing nexus of ontological and epistemological dimensions quite refreshing. Provided that we challenge contemporary works from this particular perspective, The Intercorporeal Self serves as an important resource for thinking about the current methods of research. As such, this highly recommended work fulfilled its aims in a truly inspirational manner.

\section{References}

Gibson, J. J. 1979. The Ecological Approach to Visual Perception. Boston: Houghton Mifflin Co.

O'Regan, J. K. \& Noe, A. 2001a. Authors Response, in: Behavioural and Brain Sciences, 24 2001: 1011-1031.

O'Regan, J. K. \& Noe, A. 2001b. A Sensorimotor Account on Vision and Visual Consciousness. Behavioral and Brain Sciences, 24(5): 939-973.

Thompson, E. 2005. Sensorimotor Subjectivity and the enactive approach to subjective experience. Phenomenology and Cognitive Sciences, 4 2005L: 407-427

Zahavi, D. 2005. Subjectivity and Selfhood. Cambridge: MA: MIT Press.

Gallagher, S. 2005. How the Body Shapes the Mind. Oxford: Clarendon Press.

Derrida, J. 2005. On Touching-Jean-Luc Nancy. Stanford University Press. 